\title{
Helminth fauna parasitizing Pimelodus pobli (Actinopterygii: Pimelodidae) from the upper Sáo Francisco River, Brazil
}

\author{
Helmintofauna de Pimelodus pohli (Actinopterygii: Pimelodidae) do alto rio São Francisco, Brasil \\ Claudia Silveira São Sabas ${ }^{1}$; Marilia Carvalho Brasil-Sato ${ }^{2 *}$

\begin{abstract}
${ }^{1}$ Curso de Pós-graduação em Ciências Veterinárias, Departamento de Parasitologia Animal, Universidade Federal Rural do Rio de Janeiro - UFRRJ, Seropédica, RJ, Brasil
\end{abstract} \\ ${ }^{2}$ Departamento de Biologia Animal, Universidade Federal Rural do Rio de Janeiro - UFRRJ, Seropédica, RJ, Brasil
}

Received July 7, 2014

Accepted August 5, 2014

\begin{abstract}
The parasite fauna of catfish, Pimelodus pohli, from the São Francisco River Basin is presented. A total of 45 catfish

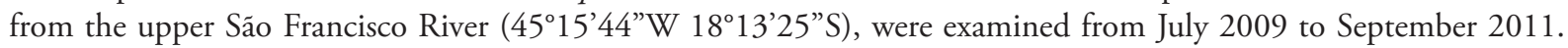
Forty-three catfish $(95.5 \%)$ were infected by at least one parasite species, with 885 parasite specimens being found, distributed across 17 species: Monogenea (Demidospermus uncusvalidus, Pavanelliella pavanellii, and Scleroductus sp.); Eucestoda (plerocercoids of Proteocephalidea); Digenea (metacercariae of Austrodiplostomum compactum, adults of Auriculostoma platense and Kalipharynx sp., and juvenile of Prosthenhystera obesa); Nematoda (larvae of Contracaecum sp., Hysterothylacium sp., Procamallanus pimelodus, Procamallanus sp., and unidentified of Cucullanidae, and adults of Cucullanus caballeroi, Philometra sp., and Procamallanus freitasi); and Acanthocephala (adults of Neoechinorhynchus pimelodi). Procamallanus freitasi and Scleroductus sp. were the taxa with the highest prevalence. Demidospermus uncusvalidus, $P$. freitasi, and Scleroductus sp. were the dominant species. The host's sex did not influence parasitic indexes; however, the total length of the catfish did appear to have some influence. The parasites, with except for P. obesa, were registered for the first time in P. pohli, as well as the occurrence of Kalipharynx sp. and C. caballeroi among pimelodid hosts from São Francisco River and South America.
\end{abstract}

Keywords: Parasites of endemic fish, helminth parasites of freshwater fish, parasite community.

\section{Resumo}

A fauna parasitária de mandis, Pimelodus pohli da bacia do rio São Francisco é apresentada. Um total de 45 mandis do alto rio São Francisco ( $45^{\circ} 15^{\prime} 44^{\prime \prime W} 18^{\circ} 13^{\prime} 25^{\prime}$ S), foram examinados entre julho de 2009 e setembro de 2011. Quarenta e três mandis $(95,5 \%)$ estavam infectados por pelo menos uma espécie de parasito tendo sido encontrados 885 parasitos de 17 espécies: Monogenea (Demidospermus uncusvalidus, Pavanelliella pavanellii, and Scleroductus sp.); Eucestoda (plerocercóides de Proteocephalidea); Digenea (metacercárias de Austrodiplostomum compactum, adultos de Auriculostoma platense e Kalipharynx sp. e juvenil de Prosthenhystera obesa); Nematoda (larvas de Contracaecum sp., Hysterothylacium sp., Procamallanus pimelodus, Procamallanus sp., larvas não identificadas de Cucullanidae e adultos de Cucullanus caballeroi, Philometra sp. e Procamallanus freitasi); e Acanthocephala (adultos de Neoechinorhynchus pimelodi). Procamallanus freitasi e Scleroductus sp. foram os táxons com prevalência mais elevada. Demidospermus uncusvalidus, $P$. freitasi e Scleroductus sp. foram as espécies dominantes. O sexo dos hospedeiros náo influenciou os índices parasitários, mas houve alguma influência do comprimento total sobre eles. Os parasitos, com exceção de P. obesa, são registrados pela primeira vez em $P$. pohli, bem como a ocorrência de Kalipharynx sp. e C. caballeroi em hospedeiros pimelodídeos do rio São Francisco e da América do Sul.

Palavras-chave: Parasitos de peixe endêmico, helmintos de peixes de água doce, comunidade parasitária.

*Corresponding author: Marilia Carvalho Brasil-Sato, Departamento de Biologia Animal, Universidade Federal Rural do Rio de Janeiro - UFRRJ, BR 465, Km 7, CP 74539, CEP 23851-970, Seropédica, RJ, Brasil, e-mail: mcbsato@gmail.com 


\section{Introduction}

Pimelodus pohli Ribeiro \& Lucena, 2006, a fish species popularly known as white catfish, or "mandi-branco", is found at several localities along the São Francisco River Basin (RIBEIRO; LUCENA, 2006). According to these authors, $P$. pohli is a species identified by Britski et al. (1988) as Pimelodus sp.. As was recently described, studies referring to its biological, behavioral, and parasitological aspects are unknown, and a comparison of its fauna with that of Pimelodus maculatus Lacepède, 1803 (congeneric of the same hydric system) and other pimelodids, for which its parasite faunas are already known, is urgent. Observations of the gastric content of $P$. pohli in the present study have revealed the use of aquatic invertebrates (insects, small arachnids, and crustaceans) and sediments as elements of its diet. Taking into account the study on the feeding habits of fish in the upper São Francisco River, as conducted by Alvim (1999), P. pohli may be considered a generalistic invertivorous and iliophagous. Thus, the endohelmintic fauna recorded in that study must reflect these feeding habits.

In the São Francisco River Basin, the records on the parasite fauna of pimelodids were established for Conorhynchos conirostris (Valenciennes, 1840) by Pinto et al. (1974), Pinto and Noronha (1976), Vicente et al. (1985), and Brasil-Sato and Santos (2005); for Pseudoplatystoma corruscans (Spix \& Agassiz, 1829) by Rego and Gibson (1989), Kohn et al. (1997), and Corrêa and Brasil-Sato (2008); for Bergiaria westermanni (Lütken, 1874) by Moreira et al. (1991) and Vicente and Pinto (1999); for P. maculatus by BrasilSato and Pavanelli (1998, 1999, 2000, 2004), Brasil-Sato (2003), and Monteiro et al. (2010); and for P. pohli by Martins et al. (2012). In this last work, the authors have established the first record of a parasite species, Prosthenhystera obesa (Diesing, 1850), in the gall bladder of $P$. pohli.

Studies on parasitism in pimelodids have been also conducted in other localities of Brazil, such as some helminth parasites of species of Pimelodus Lacepède, 1803: P. blochii Valenciennes, 1840 in Paraná River (KOHN et al., 1997); P. fur (Lütken, 1874) in Paraná River (KOHN et al., 1997); P. maculatus in Amazon Basin (KOHN et al., 2011); in Guaiba River (KOHN; FRÓES, 1986; FORTES et al., 1993; FORTES; HOFFMANN, 1995; SARMENTO et al., 1995); in Guandu River (SANTOS et al., 2007; ALBUQUERQUE et al., 2008; AZEVEDO et al., 2010); in Itajaí-Açu River (BACHMANN et al., 2007); in Mogi Guaçu River (TRAVASSOS; KOHN, 1965; KOHN et al., 1985; KOHN; FERNANDES, 1987; AGUIAR et al., 2011); in Paraiba do Sul River (VENANCIO et al., 2010); in Paraná River (TRAVASSOS; KOHN, 1965; PAVANELLI; MACHADO DOS SANTOS, 1992; MORAVEC et al., 1993, 1997; KOHN et al., 1997; BRASIL-SATO; PAVANELLI, 2004; COHEN; KOHN, 2008; KOHN et al., 2011; LOPES et al., 2011); in Paranapanema River (RAMOS et al., 2013); Pimelodus microstoma Steindachner, 1877 in Mogi Guaçu River (AGUIAR et al., 2011) [note of the authors: this fish species was cited by the authors as $P$. heraldoi Azpelicueta, 2001, that is a junior synonym of P. microstoma Stein., sensu Ribeiro and Lucena (2010)]; Pimelodus ornatus Kner, 1858 in Paraná River (PAVANELLI; TAKEMOTO, 1996; PAVANELLI et al., 1997;
FERNANDES; KOHN, 2001; KOHN et al., 2011); Pimelodus sp. in Amazon Basin (VICENTE et al., 1978). Through a literature review, it was possible to verify at least 131 species of helminths recorded among the pimelodids distributed in the Brazilian basins.

In this study, the helminth fauna of $P$. pohli is presented for the first time in the São Francisco River Basin, contributing to the knowledge on the parasite species of fish in the São Francisco River, and on the parasite species of pimelodids in the hydrographic basins in South America.

\section{Materials and Methods}

A total of 45 specimens of $P$. pohli were collected from July 2009 to September 2011 in the upper São Francisco River, downstream from the Três Marias Reservoir (4515'44”W, 18¹3'25”S) in the municipality of Três Marias, State of Minas Gerais, Brazil. The fish were captured by local fishers and were sent to the Centro Integrado de Recursos Pesqueiros e Aquicultura (CIRPA) of the Companhia de Desenvolvimento dos Vales do São Francisco e do Parnaíba (CODEVASF), where they were weighted (average body weight: $26.6 \pm 11 \mathrm{~g}$ ), measured (average total length: $14.5 \pm 1.6 \mathrm{~cm}$ ), and necropsied to investigate their parasite fauna. Voucher specimens of $P$. pohli were deposited in the Coleção de Peixes of the Museu de Zoologia of the Universidade de São Paulo (MZUSP: 105895), State of Sáo Paulo, Brazil. Parasite voucher specimens were deposited in the Coleção Helmintológica of the Instituto Oswaldo Cruz (CHIOC), Rio de Janeiro, Brazil, under the numbers indicated in Table 1 of the Results section.

Ecological descriptors (prevalence, mean abundance, and mean intensity) were calculated according to Bush et al. (1997). The dispersion index was calculated for each species in order to determine the distribution standard of the species; it was tested by calculating the $d$ statistic (LUDWIG; REYNOLDS, 1988). The interaction between couples of species co-occurring within the hosts was evaluated via the chi-square test $\left(\chi^{2}\right)$ with Yates's correction and a $2 \times 2$ contingency table, and by Spearman's rank correlation coefficient $(r s)$. Student's $t$-test was used to evaluate the total length among the male and female hosts. Spearman's rank correlation coefficient ( $r s$ ) was used to verify possible correlations between the total length of hosts and parasite abundance and intensity. Pearson's correlation coefficient $(r)$ was used to determine possible correlations between the total length of the hosts and parasite prevalence. The influence of the host's sex on parasite abundance and prevalence was tested using the normal approximation of $Z$ via the Mann-Whitney $U$ test and the chi-square test $\left(\chi^{2}\right)$ with Yates's correction and a $2 \times 2$ contingency table, respectively. The statistical analysis was performed according to Zar (1996), and was applied to the study of parasite infracommunities among P. pohli, but only for species with a prevalence rate higher than $10 \%$ (BUSH et al., 1990). The adopted significance level was $p<0.05$.

\section{Results}

Among the 45 examined specimens of $P$. pohli, 18 (40\%) were male and $27(60 \%)$ were female (representing a ratio of 1:1.5). Male and female catfish presented with a mean total length of 
Table 1. Ecological describers (prevalence, mean intensity, intensity amplitude, mean abundance), and site of infestation/infection of helminth parasites (the developmental stages of the parasite specimens, except for adults, were indicated in parentheses following the nominal taxa) of Pimelodus pohli Ribeiro \& Lucena, 2006 from the upper São Francisco River, State of Minas Gerais, Brazil.

\begin{tabular}{|c|c|c|c|c|c|}
\hline Parasite & $\begin{array}{l}\text { Prevalence } \\
(\%)\end{array}$ & $\begin{array}{c}\text { Mean } \\
\text { intensity }\end{array}$ & $\begin{array}{l}\text { Intensity } \\
\text { amplitude }\end{array}$ & $\begin{array}{c}\text { Mean } \\
\text { abundance }\end{array}$ & Site \\
\hline \multicolumn{6}{|l|}{ Monogenea } \\
\hline $\begin{array}{l}\text { Demidospermus uncusvalidus Gutierrez \& Suriano, } 1992 \\
\text { (CHIOC n.37922, 37923) }\end{array}$ & 51.1 & $17.22 \pm 19.73$ & $1-78$ & $8.80 \pm 16.44$ & Gill filaments \\
\hline $\begin{array}{l}\text { Pavanelliella pavanellii Kritsky \& Boeger, } 1998 \text { (CHIOC } \\
\text { n.37921) }\end{array}$ & 4.4 & 1 & 1 & $0.04 \pm 0.21$ & Nasal cavity \\
\hline Scleroductus sp.(CHIOC n.37924) & 62.2 & $4.86 \pm 5.76$ & $1-23$ & $3.02 \pm 5.10$ & Body surface \\
\hline \multicolumn{6}{|l|}{ Digenea } \\
\hline $\begin{array}{l}\text { Austrodiplostomum compactum (Lutz, 1928) (metacercariae) } \\
\text { (CHIOC n.37927) }\end{array}$ & 35.5 & $2.25 \pm 2.57$ & $1-10$ & $0.80 \pm 1.85$ & Eyes \\
\hline Auriculostoma platense (Szidat,1954) (CHIOC n.37926) & 6.6 & $19.67 \pm 31.47$ & $1-56$ & $1.31 \pm 8.34$ & Anterior intestine \\
\hline $\begin{array}{l}\text { Prosthenhystera obesa (Diesing, 1850) (juvenile) (CHIOC n. } \\
\text { 37732) }\end{array}$ & 2.2 & 1 & 1 & $0.02 \pm 0.15$ & Gall bladder \\
\hline Kalipharynx sp. & 2.2 & 3 & $1-3$ & $0.07 \pm 0.45$ & Coelom \\
\hline \multicolumn{6}{|l|}{ Cestoda } \\
\hline Proteocephalidea (plerocercoids) (CHIOC n.37928) & 6.7 & $2.70 \pm 2.10$ & $1-5$ & $0.18 \pm 0.80$ & Intestine \\
\hline \multicolumn{6}{|l|}{ Nematoda } \\
\hline Contracaecum sp. (larvae) (CHIOC n.35922) & 17.8 & $3.00 \pm 2.14$ & $1-6$ & $0.53 \pm 1.44$ & Coelom \\
\hline Cucullanus caballeroi Petter, 1977 (CHIOC n.35915, 35916) & 6.7 & 1 & 1 & $0.02 \pm 0.15$ & $\begin{array}{l}\text { Anterior and } \\
\text { posterior intestine }\end{array}$ \\
\hline Cucullanidae (larvae unidentified) (CHIOC n.35914) & 4.4 & 1 & 1 & $0.04 \pm 0.21$ & Coelom \\
\hline Hysterothylacium sp. (larvae) (CHIOC n.35917) & 2.2 & 1 & 1 & $0.02 \pm 0.15$ & Coelom \\
\hline Philometra sp. (CHIOC n.35923) & 2.2 & 1 & 1 & $0.02 \pm 0.15$ & Coelom \\
\hline $\begin{array}{l}\text { Procamallanus freitasi (Moreira, Oliveira \& Costa, 1991) } \\
\text { (CHIOC n.35920, 35921) }\end{array}$ & 64.4 & $5.55 \pm 5.78$ & $1-24$ & $3.58 \pm 5.34$ & $\begin{array}{l}\text { Anterior, middle and } \\
\text { posterior intestine }\end{array}$ \\
\hline $\begin{array}{l}\text { Procamallanus pimelodus (Pinto, Fábio, Noronha \& Rolas, } \\
\text { 1974) (larvae) (CHIOC n.35918) }\end{array}$ & 6.7 & $1.33 \pm 0.58$ & $1-2$ & $0.09 \pm 0.36$ & Middle intestine \\
\hline $\begin{array}{l}\text { Procamallanus (Spirocamallanus) sp. (larvae) (CHIOC } \\
\text { n.35919) }\end{array}$ & 24.4 & $3.82 \pm 3.65$ & $1-11$ & $0.93 \pm 2.41$ & $\begin{array}{l}\text { Anterior and middle } \\
\text { intestine }\end{array}$ \\
\hline \multicolumn{6}{|l|}{ Acanthocephala } \\
\hline $\begin{array}{l}\text { Neoechinorhynchus pimelodi Brasil-Sato \& Pavanelli, } 1998 \\
\text { (CHIOC n. 37925) }\end{array}$ & 11.6 & $1.20 \pm 0.44$ & $1-2$ & $0.13 \pm 0.40$ & Anterior intestine \\
\hline
\end{tabular}

$14.3 \pm 1.4 \mathrm{~cm}$ and $14.7 \pm 1.7 \mathrm{~cm}$, respectively, and a mean body weight of $25.6 \pm 9.8 \mathrm{~g}$ and $28.2 \pm 13.2 \mathrm{~g}$, respectively. There was no significant difference in the total length $(t=0.84 ; p=0.20)$ and weight $(t=0.75 ; p=0.45)$ between male and female hosts.

Among the examined hosts, 43 (95.5\%) were infected by at least one parasite species. A total of 885 parasites were found, and those represented the following taxa: Monogenea (three species); Eucestoda (one species); Digenea (four species); Nematoda (eight species); and Acanthocephala (one species) (Table 1).

Nematoda and Monogenea were the taxa whose prevalence values were higher, representing $82 \%$ and $75 \%$, respectively, of the total fauna.

In Nematoda, the adult specimens of Procamallanus freitasi (Moreira, Oliveira \& Costa, 1991) presented with a higher prevalence rate, mean abundance, and mean intensity, followed by Procamallanus (Spirocamallanus) sp. and Contracaecum sp., respectively, which consisted of specimens at the larval stage. In Monogenea, Scleroductus sp. presented with the highest prevalence rate, and Demidospermus uncusvalidus Gutiérrez \& Suriano, 1992, was the most abundant species with the highest mean intensity (Table 1).

The parasite community of $P$. pohli demonstrated the standard aggregated distribution pattern, except for the uniform distribution of Neoechinorhynchus pimelodi Brasil-Sato \& Pavanelli, 1998. The dominance frequency and mean relative dominance of the parasite community were most marked in D. uncusvalidus, followed by $P$. freitasi and Scleroductus sp.. The frequency of shared dominance was highest in P. freitasi and Scleroductus sp., respectively (Table 2).

There was no correlation between the host's sex and the parasitic indexes prevalence and abundance $\left(D\right.$. uncusvalidus: $\chi^{2}=0.18$, $Z=-0.81$; Scleroductus sp.: $\chi^{2}=1.14, Z=-0.75 ; A$. compactum $\chi^{2}=0.33, Z=-0.65$; Contracaecum sp.: $\chi^{2}=0.06, Z=-0.08$; P. freitasi: $\chi^{2}=0.01, Z=-0.20 ;$ Procamallanus $(S$. $)$ sp.: $\chi^{2}=0.49$, $Z=-0.35 ; N$. pimelodi: $\chi^{2}=0.64, Z=0.99$, respectively, $p>0.05$ for each result).

The total length of the hosts negatively influenced the parasitic indexes of the parasite fauna of $P$. pohli - that is, the intensity and abundance of $D$. uncusvalidus, the abundance of Contracaecum 
sp., and the prevalence of $P$. freitasi, were highest in fish with a smaller total length (Table 3).

Among the co-occurring species, the couples D. uncusvalidus - Scleroductus sp. and P. freitasi - N. pimelodi presented their correlated abundances (Table 4).

\section{Discussion}

Nematodes, both at their larval stage and as adults, are common parasites of freshwater fish, and they can attack all organs in the body; many of them are known to be disease agents in fish and humans (MORAVEC, 1998). Nematoda was the prevailing taxon in several studies on the helminth fauna of $P$. maculatus. In Brazil, Kohn and Fernandes (1987) recorded the occurrence of Cucullanus pinnai Travassos, Artigas \& Pereira, 1928, as the most prevailing parasite in the Mogi Guaçu River, State of São Paulo, followed by Cucullanus sp. and Procamallanus pimelodus (Pinto, Fabio, Noronha \& Rolas, 1974); Bachmann et al. (2007) recorded the highest prevalence of camallanids ( $P$. pimelodus) in the ItajaíAçu River, State of Santa Catarina. The highest prevalence was noted among cucullanids (C. pinnai) by Santos et al. (2007) and

Table 2. Values of dominance frequency, mean relative dominance, shared dominance frequency, dispersion index, and $d$ statistic of helminth parasites of Pimelodus pohli Ribeiro \& Lucena, 2006 from the upper São Francisco River, State of Minas Gerais, Brazil.

\begin{tabular}{|c|c|c|c|c|c|}
\hline Parasite & $\begin{array}{l}\text { Dominance } \\
\text { Frequency }\end{array}$ & $\begin{array}{c}\text { Mean relative- } \\
\text { dominance }\end{array}$ & $\begin{array}{c}\text { Shared domi- } \\
\text { nance frequency }\end{array}$ & $\begin{array}{l}\text { Dispersion } \\
\text { Index }\end{array}$ & $d$ Statistic \\
\hline \multicolumn{6}{|l|}{ Monogenea } \\
\hline Demidospermus uncusvalidus & 17 & $0.26 \pm 0.29$ & 12 & 30.72 & $41.61^{*}$ \\
\hline Scleroductus sp. & 6 & $0.20 \pm 0.24$ & 22 & 8.62 & $17.15^{*}$ \\
\hline \multicolumn{6}{|l|}{ Digenea } \\
\hline Austrodiplostomum compactum & 3 & $0.07 \pm 0.14$ & 13 & 4.29 & $9.06^{*}$ \\
\hline \multicolumn{6}{|l|}{ Nematoda } \\
\hline Contracaecum sp. & 2 & $0.05 \pm 0.17$ & 5 & 3.88 & $8.10^{*}$ \\
\hline Procamallanus freitasi & 7 & $0.21 \pm 0.26$ & 22 & 7.97 & $16.10^{*}$ \\
\hline $\begin{array}{l}\text { Procamallanus (Spirocamallanus) sp. } \\
\text { Acanthocephala }\end{array}$ & 1 & $0.04 \pm 0.11$ & 7 & 6.2 & $12.98^{*}$ \\
\hline Neoechinorhynchus pimelodi & 0 & $0.01 \pm 0.03$ & 4 & 1.22 & 0.01 \\
\hline
\end{tabular}

*Significant values: $d>1.96$

Table 3. Influence of host length in prevalence (Pearson's $(r)$ correlation coefficient), intensity, and abundance (Spearman's rank ( $r s$ ) correlation coefficient) of helminth parasites of Pimelodus pohli Ribeiro \& Lucena, 2006 from the upper São Francisco River, State of Minas Gerais, Brazil.

\begin{tabular}{|c|c|c|c|c|c|c|}
\hline \multirow[t]{2}{*}{ Parasite } & \multicolumn{2}{|c|}{ Prevalence } & \multicolumn{2}{|c|}{ Intensity } & \multicolumn{2}{|c|}{ Abundance } \\
\hline & $r$ & $p$ & $r s$ & $p$ & $r s$ & $p$ \\
\hline \multicolumn{7}{|l|}{ Monogenea } \\
\hline Demidospermus uncusvalidus & -0.96 & 0.18 & -0.42 & $0.04^{*}$ & -0.38 & $0.009^{*}$ \\
\hline Scleroductus sp. & -0.88 & 0.25 & -0.29 & 0.13 & 0.08 & 0.6 \\
\hline \multicolumn{7}{|l|}{ Digenea } \\
\hline Austrodiplostomum compactum & 0.97 & 0.12 & 0.24 & 0.36 & 0.21 & 0.15 \\
\hline \multicolumn{7}{|l|}{ Nematoda } \\
\hline Contracaecum sp. & -0.30 & 0.8 & -0.24 & 0.56 & -0.33 & $0.02^{*}$ \\
\hline Procamallanus freitasi & -0.99 & $0.02 *$ & 0.04 & 0.83 & -0.14 & 0.34 \\
\hline Procamallanus (Spirocamallanus) sp. & -0.55 & 0.62 & -0.05 & 0.87 & -0.16 & 0.29 \\
\hline \multicolumn{7}{|l|}{ Acanthocephala } \\
\hline Neoechinorhynchus pimelodi & 0.97 & 0.12 & 0.35 & 0.51 & -0.44 & 0.77 \\
\hline
\end{tabular}

*significant values: $p<0.05$.

Table 4. Couples of co-occurring species of helminth parasites of Pimelodus pohli Ribeiro \& Lucena, 2006 from the upper São Francisco River, State of Minas Gerais, Brazil

\begin{tabular}{lccc}
\hline \multicolumn{1}{c}{ Co-occurring Species } & Prevalence & Abundance \\
\hline $\begin{array}{l}\text { Ectoparasites (adults) } \\
\text { Demidospermus uncusvalidus - Scleroductus sp. }\end{array}$ & $\chi^{2}$ & $\boldsymbol{p}$ & $\boldsymbol{p}$ \\
$\begin{array}{l}\text { Endoparasites (adults) } \\
\text { Procamallanus freitasi - Neoechinorhynchus pimelodi }\end{array}$ & 2.74 & 0.09 & 0.34 \\
$\begin{array}{l}\text { Endoparasites (larvae) } \\
\text { Contracaecum sp. - Procamallanus (Spirocamallanus) sp. }\end{array}$ & 0.72 & $0.02^{*}$ \\
\hline
\end{tabular}

(Chi-square test $\left(\chi^{2}\right)$ with Yates's correction; Spearman's rank $(r s)$ correlation coefficient. ${ }^{*}$ significant values: $\left.p<0.05\right)$. 
Albuquerque et al. (2008) in the Guandu River, State of Rio de Janeiro; Venancio et al. (2010) found that $C$. pinnai was the sole helminth in the fauna, presenting with a high prevalence rate in this host in the Paraíba do Sul River, State of Rio de Janeiro. In addition to the occurrence of these nematodes in high indexes in several hydrographic basins, Cucullanus spp. [especially $C$. pinnai (cucullanids) and Procamallanus spp. (camallanids)] have been constantly presented in the parasite fauna of $P$. maculatus. In this study, $P$. freitasi was the species that presented the highest prevalence among the endoparasites of $P$. pohli, with remarkable record of larvae of Procamallanus sp. and P. pimelodus, as well as adults of Cucullanus caballeroi Petter, 1977; this pattern was relevant, as it showed the same structural composition of the representative cucullanid and camallanid species in the helminth fauna of congeneric pimelodid hosts. This parasite-host relationship had been cited for pimelodid hosts in the Mogi Guaçu (KOHN; FERNANDES, 1987), Paraná (PAVANELLI et al., 1997), and São Francisco Rivers (BRASIL-SATO, 2003) when, in addition to the Eucestoda larvae, Nematoda was highlighted as a common parasite that was represented by the larvae of the species allotted to Anisakidae, the species of Procamallanus Baylis, 1923, Cucullanus Müller, 1777 and, among the latter, C. pinnai (BRASIL-SATO, 2003).

In addition to the ecological aspects that involve the use of alimentary items that predispose congeneric hosts to the same types of parasites, and which lead to the parasite-host specificity in several hydrographic basins listed in this study, it is equally significant to add that $P$. freitas $i$ indexes were significantly higher in smaller specimens of $P$. pohli - an endemic species to the São Francisco River.

Procamallanus spp. perforate the intestinal wall of hosts with their buccal capsule and feed on blood; these nematodes are commonly found upon necropsy, and are red or dark brown in color due to such hematophagous activity (BRASIL-SATO, 2003). They can cause inflammatory reactions at the place where they adhere to, and they may cause anemia in the host due to blood loss. They can occupy the intestinal lumen in small or juvenile fish and, if they do not cause death under such conditions, they can affect growth (THATCHER, 2006). Besides the availability of the intermediate host (crustaceans and insects), which justifies the constant record of C. pinnai in Pimelodus spp., Albuquerque et al. (2008) have also suggested the possibility of a histotrophic phase in $C$. pinnai cycle. As most Brazilian rivers are related to reservoirs with hydroelectric potential, the abundance of nematodes may be enhanced, i.e. the parasitic transmission can be faster and/or more efficient among the hosts kept in smaller areas (e.g., due to fragmentation of the rivers and also due changing the flow of the rivers). Host abundance is favored in lentic environments, such as in lakes and dams (MORAVEC, 1998), and thus high indexes of infection by nematodes are found in the fish species that dwell in areas close to the reservoirs of hydroelectric power stations (FELTRAN et al., 2004). Therefore, all of these aspects must be considered in proposals that suggest raising Pimelodus spp. under confined conditions, and a lot of attention must be paid to parasitism in endemic species, such as $P$. pohli (endemic to the São Francisco River), when dealing with biodiversity preservation in aquatic systems.
The development stage and the parasitic indexes of $P$. freitasi and $C$. caballero $i$ have suggested that $P$. pohli serves as the definitive host for those nematodes, and as an intermediate host for the larvae of Contracaecum sp. and Hysterothylacium sp., which will become adult specimens in birds, according to Moravec (1998).

Santos et al. (2007) and Gutiérrez and Martorelli (1999) recorded high prevalence values for $D$. uncusvalidus and low prevalence rates for Scleroductus sp. in P. maculatus in the Guandu River, Brazil and in the la Plata River, Argentina, respectively. In the present study, the prevalence of Scleroductus sp. and the prevalence and mean intensity of D. uncusvalidus were high. In the upper São Francisco River, these two direct-transmission ectoparasite species (THATCHER, 2006) are the ones that characterized the ectoparasite community of $P$. pohli (mainly in fish with smaller body sizes), and the high values of their parasitic indexes optimized the observed co-occurrence.

The biometric data of siluriform hosts have been analyzed and were related to the parasitic indexes in several works (MACHADO et al., 1994; BRASIL-SATO; PAVANELLI, 2004; BRASIL-SATO; SANTOS, 2005; MOREIRA et al., 2005; SANTOS; BRASIL-SATO, 2006; BACHMANN et al., 2007). In the São Francisco River, parasitic indexes have been minimally influenced by fish size, and the possible cumulative effect of parasites, as proposed by Rohde (1993), has not been observed in parasite communities of fish in that hydric system. In this study, smaller fish presented with a higher abundance of ectoparasites $(D$. uncusvalidus) and, except for $A$. compactum, endohelminths also had their abundance favored, with the number of larval specimens of Contracaecum sp. and adults of $P$. freitasi being significantly higher in smaller $P$. pohli (Table 4). For camallanid nematodes, it is possible that the smaller fish presented with predilection for some alimentary items such as copepods, which were indicated as intermediate hosts for these parasites by Moravec (1998).

The sex of siluriform hosts has not been a determining factor in the structure of fish in the São Francisco River. In the present study, and in the studies conducted by Brasil-Sato and Santos (2005) and Santos and Brasil-Sato (2004, 2006), in the São Francisco River, there was no influence of host sex on the parasitic indexes, and this fact was supported by the similarities in feeding strategies and habits observed between male and female hosts.

Sympatric or related hosts must be similar in composition to their parasite faunas due to the level of similarity in their biological and behavioral features. In the São Francisco River, Pinto et al. (1974), Pinto and Noronha (1976), and Vicente et al. (1985) reported on the larvae of Procamallanus (Spirocamallanus) sp. in Conorhynchos conirostris, and Moreira et al. (1991) and Vicente and Pinto (1999) recorded P. freitasi in B. westermanni. BrasilSato (2003) recorded the following helminths in P. maculatus: Demidospermus sp., Vancleaveus sp., Pavanelliella pavanellii Kritsky \& Boeger, 1998; Monticellia loyolai Pavanelli \& Machado dos Santos, 1992 and Nomimoscolex sp. - two proteocephalid cestode species, one them presenting with larval specimens; Auriculostoma platense (Szidat, 1954) Scholz, Aguirre-Macedo and Choudhury, 2004 (cited as the original combination: Crepidostomum platense Szidat, 1954), Creptotrema creptotrema Travassos, Artigas \& Pereira, 1928, Sanguinicola coelomica (Szidat, 1951) Gibson and Bray, 2002 (cited as the original combination: Plehniella coelomica Szidat, 
1951), Prosthenhystera obesa (Diesing, 1850), Thometrema overstreeti Brooks, Mayers \& Thorson, 1979, a digenean species identified in this study (Kalipharynx sp.), metacercariae of Clinostomum sp. and Diplostomum sp. (=Austrodiplostomum sp.) ; C. pinnai, Dichelyne sp., Philometra sp., P. freitasi, larval specimens of unidentified nematodes; and $N$. pimelodi. Larvae of Procamallanus (Spirocamallanus) sp. were recorded by Brasil-Sato and Santos (2005) in C. conirostris. Thus, among the species already recorded in pimelodids in the São Francisco Basin, the following parasites were found in $P$. pohli in this study: P. pavanellii, plerocercoids of Proteocephalidea, $A$. platense, P. obesa, Kalipharynx sp., Philometra sp., P. freitasi, larvae of Contracaecum sp., and $N$. pimelodi.

In other localities, some these common helminths species were also found in pimelodids. Regarding the Monogenea, in the Baia (type-locality) and Paraná Rivers, Pavanelliella pavanelii was described of $P$. corruscans by Kritsky and Boeger (1998) and they also reported this monogenean species of Callophysus macropterus (Lichtenstein, 1819) from Solimóes River; P. pavanellii was recorded by Lopes et al. (2009) from Negro and Solimóes Rivers in Pseudoplatystoma tigrinum (Spix \& Agassiz, 1829) (sic) and Pseudoplatystoma punctifer (Linnaeus, 1766) (sic) [note of the authors: $P$. tigrinum as cited by the authors is P. tigrinum (Valenciennes, 1840), and $P$. punctifer refers to $P$. punctifer (Castelnau, 1855) sensu Buitrago-Suárez and Burr (2007)]. In the Guandu River, Santos et al. (2007) found Demidospermus uncusvalidus Gutiérrez \& Suriano, 1992 and Scleroductus sp.; and in the Mogi Guaçu River, Aguiar et al. (2011) recorded $P$. pavanellii of $P$. maculatus. With respect to the Digenea, in the Guaiba River, A. platense (as C. platense) was found parasitizing $P$. maculatus by Kohn and Fróes (1986) and Fortes et al. (1993), respectively; in the Paraná Basin, the six Digenea species cited in $P$. maculatus from São Francisco River were common in the fauna of $P$. maculatus and their indexes were recorded and compared by Brasil-Sato and Pavanelli (2004); and in the Guandu River, Santos et al. (2007) and Azevedo et al. (2010), recorded $A$. compactum parasitizing $P$. maculatus. With relation to the Nematodes, in the Paraná Basin, Machado et al., $(1994,1995,1996)$ recorded Contracaecum sp. and Procamallanus (S.) sp. of P. corruscans; and Guidelli et al. (2003) recorded larvae of Contracaecum sp. in Hemisorubim platyrhynchos (Valenciennes, 1840); and In the Aquidauana River, Campos et al. (2008) recorded larvae of Contracaecum sp. in Pseudoplatystoma fasciatum (L., 1766). Among the helminths recorded in P.pohli, $N$. pimelodi - the sole acanthocephalan species - was described from the parasite specimens of the congeneric $P$. maculatus and was recorded by Santos and Brasil-Sato (2006) in Franciscodoras marmoratus Reinhardt, 1874 (Siluriformes, Doradidae) in the São Francisco River (type-locality). Recently, Lopes et al. (2011) recorded $N$. pimelodi in $P$. maculatus and $B$. westermanni in the Paraná Basin. In the parasite community of $P$. pohli, $N$. pimelodi was the only one with a uniform distribution, but in the congeneric host $P$. maculatus, its distribution was widely dispersed, both during periods of flooding and drought in the upper São Francisco River region (BRASIL-SATO; PAVANELLI, 1999).

In this study, it is suggested that the co-occurrence of endoparasites $P$. freitasi and $N$. pimelodi was due to the use of arthropods, intermediate hosts, in the diet of $P$. pohli.
The significance of the analysis of parasitic indexes among host species with a wide distribution in the South American hydrographic basins, and among congeneric and sympatric species in this region, is highlighted to detect the main groups of parasite species that are able to affect fish. This type of predictive analysis indicates the relative specificity of parasite-host relationships in the hydrographic basins. The parasitism analysis of $P$. pohli highlighted that the smaller specimens were significantly more infested by Monogenea and infected by Nematoda; P. pohli is an endemic pimelodid host, whose niche and immunological plasticity is related to the available habitats that is restricted to the São Francisco River in relation to congeneric species or other pimelodids that present with a wide geographic distribution in the South and Central Americas. It was reinforced that, among the endoparasites, cucullanid and camallanid nematodes are the parasite representatives that prevail in the parasite fauna of the Pimelodus species. For P. pohli, the presence and parasitic indexes of those nematodes (as well as the endoparasite community) prove its invertivorous alimentary habits, which were not previously known.

In this study, the parasite species of $P$. pohli were presented, as well as those that are common in the fauna of $P$. maculatus in the São Francisco River and other basins. With the exception of $P$. obesa, which was recorded in P. pohli by Martins et al. (2012), this study revealed the parasite community of $P$. pohli and highlighted the first record of Kalipharynx sp. and C. caballeroi in the parasite community of fish in the upper São Francisco River, and in the pimelodids from South America.

\section{Acknowledgments}

The authors are grateful to Dr Yoshimi Sato (CODEVASF, Três Marias, MG) for the resources and scientific information available about the host and to the working arrangement CEMIG-GT/ CODEVASF for providing logistical and material support; to Dr Osvaldo Takeshi Oyakawa and to Dr Marcelo Knoff for his kindness in receiving the voucher specimens sent for deposit at the MZUSP and CHIOC, respectively. To CAPES for scholarship to first author and for funded this research (Edital 032/2010 Parasitologia Básica).

\section{References}

Aguiar JC, Ceccarelli PS, Luque JL. Two new species of Pavanelliella (Monogenea, Dactylogyridae) parasitic on pimelodid fishes from Mogi Guaçu river, southeastern Brazil, and notes on the morphology of P. pavanellii. Neotrop Helminthol 2011; 5(2): 213-224.

Albuquerque MC, Santos MD, Monteiro CM, Martins AN, Ederli NB, Brasil-Sato MC. Helmintos endoparasitos de Pimelodus maculatus Lacépède, 1803 (Siluriformes, Pimelodidae) de duas localidades (lagoa e calha) do Rio Guandu, Estado do Rio de Janeiro, Brasil. Rev Bras Parasitol Vet 2008; 17(S1): 113-119. PMid:20059829.

Alvim MCC. Composição e alimentação da ictiofauna em um trecho ao alto rio São Francisco, município de Três Marias - MG [Dissertação]. São Carlos: Universidade Federal de São Carlos; 1999.

Azevedo RK, Abdallah VD, Luque JL. Acanthocephala, Annelida, Arthropoda, Myxozoa, Nematoda and Platyhelminthes parasites of 
fishes from the Guandu river, Rio de Janeiro, Brazil. Check List 2010; 6(4): 659-667.

Bachmann F, Greinert JA, Bertelli PW, Filho HHS, Lara NOT, Ghiraldelli L, et al. Parasitofauna de Pimelodus maculatus (Osteichthyes: Pimelodidae) do rio Itajaí-Açu em Blumenau, Estado de Santa Catarina, Brasil. Acta Sci Biol Sci 2007; 29(1): 109-114.

Brasil-Sato MC. Parasitos de peixes da bacia do São Francisco. In: Godinho HP, Godinho AL. Águas, peixes e pescadores do São Francisco das Minas Gerais. Belo Horizonte: PucMinas; 2003. p. 149-166.

Brasil-Sato MC, Pavanelli GC. Neoechinorhynchus pimelodi sp. n. (Eoacanthocephala, Neoechinorhynchidae) parasitizing Pimelodus maculatus Lacépède, "mandi-amarelo" (Siluroidei, Pimelodidae) from the basin of the São Francisco river, Três Marias, Minas Gerais, Brazil. Rev Bras Zool 1998; 15(4): 1003-1011. http://dx.doi.org/10.1590/ S0101-81751998000400019

Brasil-Sato MC, Pavanelli GC. Ecological and reproductive aspects of Neoechinorhynchus pimelodi Brasil-Sato \& Pavanelli (Eoacanthocephala, Neoechinorhynchidae) of Pimelodus maculatus Lacépède (Siluroidei, Pimelodidae) of the São Francisco river, Brasil. Rev Bras Zool 1999; 16(1): 73-82. http://dx.doi.org/10.1590/S0101-81751999000100002

Brasil-Sato MC, Pavanelli GC. Pavanelliella pavanellii Kritsky e Boeger, 1998 (Monogenea: Dactylogyridae) parasito das cavidades nasais de Pimelodus maculatus Lac., 1803, "mandi", das bacias do rio São Francisco e do rio Paraná, Brasil. Parasitol. dia 2000; 24(3-4): 123-126.

Brasil-Sato MC, Pavanelli GC. Digenea de Pimelodus maculatus (Osteichthyes, Pimelodidae) das bacias dos rios São Francisco e Paraná, Brasil. Parasitol Latinoam 2004; 59(3-4): 123-131.

Brasil-Sato MC, Santos MD. Metazoan parasites of Conorhynchos conirostris (Valenciennes, 1840), an endemic siluriform fish of the São Francisco Basin, Brazil. Rev Bras Parasitol Vet 2005; 14(4): 160-166.

Britski HA, Sato Y, Rosa ABS. Manual de identificação de peixes da região de Três Marias: com chaves de identificação para os peixes da bacia do Sáo Francisco. 3. ed. Brasília: Camara dos Deputados, Codevasf; 1988.

Buitrago-Suárez UA, Burr BM. Taxonomy of the catfish genus Pseudoplatystoma Bleeker (Siluriformes: Pimelodidae) with recognition of eight species. Zootaxa 2007; 1512: 1-38.

Bush AO, Aho JM, Kennedy CR. Ecological versus phylogenetic determinants of helminth parasite community richness. Evolut Ecol 1990; 4(1): 1-20. http://dx.doi.org/10.1007/BF02270711

Bush AO, Lafferty KD, Lotz JM, Shostak AW. Parasitology meets ecology on its own terms: Margolis et al. revisited. J Parasitol 1997; 83(4): 575583. PMid:9267395. http://dx.doi.org/10.2307/3284227

Campos CM, Fonseca VE, Takemoto RM, Moraes FR. Fauna parasitária de cachara Pseudoplatystoma fasciatum (Siluriforme: Pimelodidae) do rio Aquidauana, Pantanal Sul Mato-Grossense, Brasil. Acta Sci Biol Sci 2008; 30(1): 91-96.

Cohen SC, Kohn A. New data on species of Demidospermus (Dactylogyridae: Monogenea) parasitizing fishes from the reservoir of the Itaipu hydroelectric power station, Paraná State, Brazil, with new synonymies. Rev Bras Parasitol Vet 2008; 17(3): 167-170. http://dx.doi. org/10.1590/S1984-29612008000300011

Corrêa RFSS, Brasil-Sato MC. Digenea in the surubim Pseudoplatystoma corruscans (Spix and Agassiz, 1829) (Siluriformes: Pimelodidae) of the upper São Francisco River, State of Minas Gerais, Brazil. Braz Arch Biol Technol 2008; 51(6): 1181-1185. http://dx.doi.org/10.1590/S151689132008000600013

Feltran RB, Marçal O Jr, Pinese JF, Takemoto RM. Prevalência, abundância, intensidade e amplitude de infecção de nematóides intestinais em Leporinus friderici (Bloch, 1794) e L. obtusidens (Valenciennes, 1836) (Pisces, Anostomidae), na represa de Nova Ponte (Perdizes, MG). Rev Bras Zoociências 2004; 6(2): 169-179.

Fernandes BMM, Kohn A. On some trematodes parasites of fishes from Paraná river. Braz J Biol 2001; 61(3): 461-466. http://dx.doi. org/10.1590/S1519-69842001000300016

Fortes E, Hoffmann RP. 7 Levantamento da fauna parasitária de peixes do Lago Guaíba, Porto Alegre, Rio Grande do Sul, Brasil. Rev Bras Med Vet 1995; 17(3): 107-111.

Fortes E, Hoffmann RP, Sarmento, TM. Cucullanus fabregasi sp. n. Nematoda parasita do intestino do peixe Pimelodus maculatus Lacépède, 1803 do Rio Guaíba, Porto Alegre, Rio Grande do Sul, Brasil. Arq Fac Vet UFRGS 1993; 21: 71-76.

Guidelli GM, Isaac A, Takemoto RM, Pavanelli GC. Endoparasite infracommunities of Hemisorubim plathyrhynchos (Valenciennes, 1840) (Pisces: Pimelodidae) of the baía river, upper Paraná River floodplain, Brazil: specific composition and ecological aspects. Braz J Biol 2003; 63(2): 261-268. PMid:14509848. http://dx.doi.org/10.1590/S151969842003000200011

Gutiérrez PA, Martorelli SR. The structure of the monogenean community on the gills of Pimelodus maculatus in Río de la Plata (Argentina). Parasitology 1999; 119(2): 177-182. http://dx.doi. org/10.1017/S0031182099004606

Kohn A, Fernandes BMM. Estudo comparativo dos helmintos parasitos de peixes do Rio Mogi Guassu, coletados nas excursóes realizadas entre 1927 e 1985. Mem Inst Oswaldo Cruz 1987; 82(4): 483-500. PMid:3507917. http://dx.doi.org/10.1590/S0074-02761987000400006

Kohn A, Fróes OM. Saccocoelioides godoyi n. sp. (Haploporidae) and other trematodes parasites of fishes from the Guaiba estuary, RS, Brazil. Mem Inst Oswaldo Cruz 1986; 81(1): 67-72. http://dx.doi.org/10.1590/ S0074-02761986000100009

Kohn A, Fernandes BMM, Macedo B, Abramson B. Helminths parasites of freshwater fishes from Pirassununga, SP, Brazil. Mem Inst Oswaldo Cruz 1985; 80(3): 327-336. http://dx.doi.org/10.1590/S007402761985000300009

Kohn A, Fernandes BMM, Baptista-Farias MFD. Redescription of Prosthenhystera obesa (Diesing, 1850) (Callodistomidae, Digenea) with new host records and data on morphological variability. Mem Inst Oswaldo Cruz 1997; 92(2): 171-179. http://dx.doi.org/10.1590/S007402761997000200008

Kohn A, Moravec F, Cohen SC, Canzi C, Takemoto RM, Fernandes BMM. Helminths of freshwater fishes in the reservoir of the hydroelectric power station of Itaipu, Paraná, Brazil. Check List 2011; 7(5): 681-690.

Kritsky DC, Boeger WA. Neotropical Monogenoidea. 35. Pavanelliella pavanellii, a new genus and species (Dactylogyridae, Ancyrocephalinae) from the nasal cavities of Siluriform fishes in Brazil. J Helminthol Soc Wash 1998; 65(2): 160-163.

Lopes LPC, Varella AMB, Malta JCO. Metazoan parasites of Pseudoplatystoma punctifer (Linnaeus, 1766) and Pseudoplatystoma tigrinum (Spix \& Agassiz, 1829) Siluriformes: Pimelodidae) of the Central Amazon Basin, Brazil. Biol Geral Exper 2009; 9(2): 3-15.

Lopes MS, Fernandes BMM, Bastos OM, Cohen SC, Kohn A. New hosts for two species of Acanthocephala of fishes from Paraná River, State of Paraná, Brazil. Rev Bras Zoociências 2011; 13(1-2-3): 29-32.

Ludwig JA, Reynolds JF. Statistical ecology: a primer in methods and computing. New York: Wiley-Interscience; 1988.

Machado MH, Pavanelli GC, Takemoto RM. Influence of host's sex and size on endoparasitic infrapopulations of Pseudoplatystoma corruscans and 
Schizodon borelli (Osteichthyes) of the high Paraná river, Brazil. Rev Bras Parasitol Vet 1994; 3(2): 143-148.

Machado MH, Pavanelli GC, Takemoto RM. Influence of the type of environment and the hydrological level variation in endoparasitic infrapopulations of Pseudoplatystoma corruscans (Agassiz) and Schizodon borelli (Boulenger) (Osteichthyes) of the high Paraná River, Brazil. Rev Bras Zool 1995; 12(4): 961-976. http://dx.doi.org/10.1590/S010181751995000400023

Machado MH, Pavanelli GC, Takemoto RM. Structure and diversity of endoparasitic infracommunities and the trophic level of Pseudoplatystoma corruscans and Schizodon borelli (Osteichthyes) of the High Paraná River. Mem Inst Oswaldo Cruz 1996; 91(4): 441-448. PMid:9070406. http:// dx.doi.org/10.1590/S0074-02761996000400010

Martins AN, Sabas CSS, Brasil-Sato MC. Prosthenhystera obesa (Diesing, 1850) (Digenea, Callodistomidae) in the São Francisco River Basin, Brazil: New host records and their ecological parameters. Neotrop Helminthol 2012; 6(1): 31-41.

Monteiro CM, Kritsky DC, Brasil-Sato MC. Neotropical Monogenoidea. 55. Dactylogyrids parasitising the pintado-amarelo Pimelodus maculatus Lacépède (Actinopterygii: Pimelodidae) from the Rio São Francisco, Brazil. Syst Parasitol 2010; 76(3): 179-190. PMid:20532849. http:// dx.doi.org/10.1007/s11230-010-9250-2

Moravec F. Nematodes of freshwater fishes of the Neotropical Region. Praha: Academia; 1998.

Moravec F, Kohn A, Fernandes BMM. Nematode parasites of fishes of the Paraná river, Brazil. Part 3. Camallanoidea and Dracunculoidea. Folia Parasitol 1993; 40(3): 211-229.

Moravec F, Kohn A, Fernandes BMM. New observations on seuratoid nematodes parasitic in fishes of the Paraná River, Brasil. Folia Parasitol 1997; 44(3): 209-223.

Moreira NIB, Oliveira CL, Costa HMA. A new helminth parasite of fish: Spirocamallanus freitasi sp. n. (Nematoda-Camallanidae). Mem Inst Oswaldo Cruz 1991; 86(4): 429-431. http://dx.doi.org/10.1590/ S0074-02761991000400009

Moreira ST, Ito KF, Takemoto RM, Pavanelli GC. Ecological aspects of the parasites of Iheringichthys labrosus (Lütken, 1874) (Siluriformes: Pimelodidae) in reservoirs of Paraná basin and upper Paraná floodplain, Brazil. Acta Sci Biol Sci 2005; 27(4): 317-322.

Pavanelli GC, Machado dos Santos MH. Goezeella agostinhoi sp. n. e Monticellia loyolai sp. n., cestóides proteocefalídeos parasitas de peixes pimelodídeos do rio Paraná, Paraná, Brasil. Rev Bras Parasitol Vet 1992; 1(1): 45-50.

Pavanelli GC, Takemoto RM. Spasskyellina mandi n. sp. (Proteocephalidea: Monticelliidae), parasite of Pimelodus ornatus Kner, 1857 (Pisces: Pimelodidae) of the Paraná River, Paraná, Brazil. Mem Inst Oswaldo Cruz 1996; 91(6): 723-726. PMid:9283653. http://dx.doi.org/10.1590/ S0074-02761996000600013

Pavanelli GC, Machado MH, Takemoto RM. Fauna helmíntica de peixes do rio Paraná, regiáo de Porto Rico, Paraná. In: Vazzoler AEAM, Agostinho AA, Hahn NS. A planície de inundação do alto rio Paraná: aspectos físicos, biológicos e socioeconômicos. Maringá: EDUEM; 1997. p. 307-329.

Pinto RM, Noronha D. Procamallanus brasileiros (Nematoda, Camallanoidea): consideraçóes finais, com chave para determinação das espécies. Mem Inst Oswaldo Cruz 1976; 74(3-4): 323-339. http://dx.doi. org/10.1590/S0074-02761976000300011
Pinto RM, Fábio SP, Noronha D, Rolas FJT. Procamallanus brasileiros. Parte I (Nematoda, Camallanoidea). Mem Inst Oswaldo Cruz 1974; 72(34): 205-211. http://dx.doi.org/10.1590/S0074-02761974000200005

Ramos IP, Franceschini L, Zago AC, Zica EOP, Wunderlich AC, Carvalho ED, et al. New host records and a checklist of fishes infected with Austrodiplostomum compactum (Digenea: Diplostomidae) in Brazil. Rev Bras Parasitol Vet 2013; 22(4): 511-518. PMid:24473875. http:// dx.doi.org/10.1590/S1984-29612013000400010

Rego AA, Gibson DI. Hyperparasitism by helminths: new records of cestodes and nematodes in proteocephalid cestodes from South American siluriform fishes. Mem Inst Oswaldo Cruz 1989; 84(3): 371-376. http:// dx.doi.org/10.1590/S0074-02761989000300012

Ribeiro FRV, Lucena CAS. A new species of Pimelodus LaCépède, 1803 (Siluriformes: Pimelodidae) from the rio São Francisco drainage, Brazil. Neotrop Ichthyol 2006; 4(4): 411-418. http://dx.doi.org/10.1590/S167962252006000400004

Ribeiro FRV, Lucena CAS. Pimelodus heraldoi Azpelicueta, 2001, a junior synonym of Pimelodus microstoma Steindachner, 1877 (Siluriformes: Pimelodidae). Neotrop Ichthyol 2010; 8(2): 277-281. http://dx.doi. org/10.1590/S1679-62252010000200005

Rohde K. Ecology of marine parasites: an introduction to marine parasitology. 2nd ed. Wallingford: CAB International; 1993.

Santos MD, Brasil-Sato MC. Parasitos metazoários de Franciscodoras marmoratus (Reinhardt, 1874), "serrudo" (Siluriformes: Doradidae) do Rio São Francisco, Brasil. Rev Bras Parasitol Vet 2004; 13(1): 18-22.

Santos MD, Brasil-Sato MC. Parasitic community of Fransciscodoras marmoratus (Reinhardt, 1874) (Pisces: Siluriformes, Doradidae) from the upper São Francisco river, Brazil. Braz J Biol 2006; 66(3): 931-938. PMid:17119841. http://dx.doi.org/10.1590/S151969842006000500019

Santos MD, Lemos-Pita SRLC, Brasil-Sato MC. Metazoan parasite fauna of Pimelodus maculatus La Cépède, 1803 (Siluriformes, Pimelodidae) from the Guandu River, Rio de Janeiro State, Brazil. Acta Sci Biol Sci 2007; 29(1): 101-107.

Sarmento TM, Fortes E, Hoffmann RP. Cucullanus debacoi sp. n. Nematoda, parasito do intestino do Pimelodus maculatus Lacépède, 1803 (Pisces, Pimelodidae) do rio Guaíba, Porto Alegre, Rio Grande do Sul. A Hora Vet 1995; 15(85): 38-40.

Thatcher VE. Amazon fish parasites. 2nd. ed. Moscow: Pensoft; 2006.

Travassos LP, Kohn A. Lista dos helmintos parasitos de peixes encontrados na Estação Experimental de Biologia e Piscicultura de Emas, Pirassununga, Estado de São Paulo. Papéis Avulsos Zool 1965; 17: 35-52.

Venancio ACP, Aguiar GR, Lopes OS, Alves DR. Metazoan parasites of mandi-amarelo Pimelodus maculatus and of jundiá Rhamdia quelen (Osteichthyes: Siluriformes) of Paraíba do Sul river, Volta Redonda, Rio de Janeiro. Rev Bras Parasitol Vet 2010; 19(3): 157-163. PMid:20943019. http://dx.doi.org/10.1590/S1984-29612010000300006

Vicente JJ, Pinto RM. Nematóides do Brasil. Nematóides de peixes: atualização 1985-1998. Rev Bras Zool 1999; 16(3): 561-610. http:// dx.doi.org/10.1590/S0101-81751999000300001

Vicente JJ, Rodrigues HO, Gomes DC. Nematóides do Brasil. 1 ${ }^{\text {a }}$ parte: nematóides de peixes. Atas Soc Biol Rio de Janeiro 1985; 25: 1-79.

Vicente JJ, Santos E, Souza SV. Helmintos de peixes de rios amazônicos da coleção helmintológica do Instituto Oswaldo Cruz. I. Trematoda. Atas Soc Biol Rio de Janeiro 1978; 19: 9-15.

Zar JH. Biostatistical analysis. 3rd ed. New Jersey: Prentice-Hall; 1996. 